\title{
General Perceptions of Citizens on Anti-Coronavirus Pandemic Measures: The Case of Hong Kong
}

\author{
Leung Kin Hang Paul* \\ Department of Hospitality Management, Faculty of Management and Hospitality, Hong Kong
}

*Corresponding author: Leung Kin Hang Paul, Department of Hospitality Management, Faculty of Management and Hospitality, Hong Kong

\begin{abstract}
ARTICLE INFO
Received: 㓞 April 25, 2020

Published: 幽 May 07, 2020

Citation: Leung Kin Hang Paul. General Perceptions of Citizens on Anti-Coronavirus Pandemic Measures: The Case of Hong Kong. Biomed J Sci \& Tech Res 27(3)-2020. BJSTR. MS.ID.004517.
\end{abstract}

Keywords: Determinants; Technology Practice; Housekeeping Performance; Technology Acceptance; Employee Prospective

Abbreviations: WHO: World Health Organization; SARS: Severe Acute Respiratory Syndrome; HKSAR: Hong Kong Special Administrative Region; AFCD: Agriculture, Fisheries \& Conservation Department; LCSD: Leisure and Cultural Services Department; CHP: Centre for Health Protection

\section{Abstract}

The fears in related to the threats of the Coronavirus disease (COVID-19) were spreading wide and far since its outbreak in Wuhan, China in December 2019. COVID-19 was declared to be a Public Health Emergency if International Concern by the UN World Health Organization (WHO) on 30th January 2020 and subsequently announced as a pandemic on 11th March. As of 16 April, there were more than 2.08 million confirmed cases and over 134 thousand deaths reported. The general public's and governments' reactions to the pandemic are diverse. Owing to the lack of knowledge about the disease and the rapid development of cases, anxiety and certain level of disorders / unrest were recorded. This paper intended to document some of the critical incidents in Hong Kong and report findings related to the publics' perceptions, actions and reactions to the outbreak. Data was collected through direct observation and discussions with the key respondents.

Result seems to indicate that general public is likely to develop a strong of fear and stress over a public health incident especially when the case is something that they are not familiar with. They were exposed to a large amount of information and tend to be easier to believe negative messages. Advices and opinions from technical authorities are more prone to be trustworthy whereas those from government bodies and even international NGOs have less credibility. Some of them demonstrate a strong propensity to transfer the blame to someone and develop a sense of revulsion or strong indignation.

Owing to the closing of trust, the warning and suggestions given the government authority are often taken too lightly or even challenged. Some are quite stubborn and refuse to accept information that is not confirming their beliefs and /or experiences.

"The more you know, the less you fear."

"Technology", terms which appears all over the world within human daily lives. With the positive well-known reputation of problems solver and convenience enhancer, the uses of technology in businesses have been increasing. Meanwhile, the problems of housekeeping labor shortages and uncommon situations of technology uses shown in Hong Kong, which urged the considerations of using technology to solve the problems, encourages the hotel attractiveness and competitiveness. Consequently, the present research report had examined the critical determinants of technology practice that affecting the performance of hotel housekeeping department in Hong Kong, by completion of the literature reviews that covered several theories and technology acceptance, and the qualitative method of case study - participate observations. And the research findings shown that technology characteristics (Applicability to Job \& Convenience to Employees) and employee prospective (Learning Abilities\& Technology Knowledge, and Managerial Support \&Follow-up) as the determinants in technology practice which affects the housekeeping performance of Hong Kong hotel. And some possible recommendations were also provided based on the research results. With the 
findings and applicable insights provided, this research report is aiming to help Hong Kong hotels in achieving business success.

\section{Introduction}

Coronavirus (COVID-19) disease is infectious disease by a newly discovered corona virus. The first identified human case was in Wuhan, China in December 2019. The outbreak soon picks up its momentum and spread beyond China into the global village. The devastating cases of death rang the bell and call for international actions. The World Health Organization declared it be a Public Health Emergency of International Concern on 30th January 2020 and subsequently recognized as a pandemic on 11th March 2020. As of 23rd April, the total confirmed cases and deaths worldwide were 2,637,681 and 184,219 respectively World meters [1]. The United States alone, has over $852 \mathrm{k}$ confirmed cases and over $47 \mathrm{k}$ deaths. According to the WHO, the virus can be transmitted through droplets generated when an infected person coughs, sneezes, or exhales WHO [2]. There is no verified cure or preventive vaccine. These droplets are too heavy to hang in the air, and quickly fall on floors or surfaces. You can be infected by breathing in the virus if you are within close proximity of someone who has COVID-19, or by touching a contaminated surface and then your eyes, nose or mouth.

Despite the fatality rate of COVIN-19 (6.98\%) is much lower than that of severe acute respiratory syndrome (SARS) in 2003 (14-15\%) WHO [3] and the Middle East respiratory syndrome (MERS) in 2012 (35\%) WHO [4], the rapid and wide spreading of the disease induced public's concern. The situation worsens and triggered civil unrest. The fear among the general public continued with acute escalation, which results in sudden hype of demand for protective face mask, hand sanitizer and other cleaning detergents. It also aroused strong sentiments against the governments. There is critical gap in the body of knowledge in related the development of public crisis and the motivation behind civilian's actions. This study intended to provide some insights through an initial summary of the pandemic COVID-19 and the development of the related fear among and actions by the general public through the case of Hong Kong. It also aimed at unveiling the potential attributes that lead to the anti-government sentiments. The article concludes with administrative strategies, rather than the medical measures, for mediating public fears.

\section{Research Objectives}

The research objectives of this paper include:

1. To provide a timeline on the development of the COVID-19 outbreak in Hong Kong and the responding measures by the HKSAR Government;
2. To identify the potential attributes that lead to the sentiments of the public over the SAR Government in this regards; and

3. To provide recommendations on the prevention and management of crisis.

\section{Context and Methodology}

\section{Hong Kong}

Hong Kong, officially the Hong Kong Special Administrative Region of the People's Republic of China (HKSAR), is a city and special administrative region of China. It is located on the Pearl River Delta by the South China Sea. It has nearly 4.5 million populations as of April 2020 and a total area of 1,106 square kilometer. It is one of the most densely populated places in the world. Hong Kong was a British colony before its handover back to the People's Republic of China on 1st July 1997. As a special administrative region, Hong Kong maintains separate governing and economic systems from that of the mainland under the principle of "one country, two systems" as stipulated in its Basic Law. Hong Kong is one of the world's most significant financial centers and commercial centre. In 2019, it was ranked 15th in the world in term of GDP per capita (nominal). It is the world's tenth-largest exporter and ninth-largest importer (US CIA, 2020). Hong Kong shared the 4th place in terms of human development index with a score of 0.939 with Germany. Hong Kong came in the third place in the Global Financial Centers Index, and on the top in terms of the Index of Economic Freedom in 2019.

The city, however, has been suffering from the issues of income and wealth inequality, extreme high property prices and a relatively instable political context. The Gina coefficient based on original monthly household income in 2016 was 0.539 , which has worsened from what was 0.533 in 2006 (Oxfam, 2017). For reference, China was 465; Singapore is 459; Macau is 350 and EU is 308 (US CIA 2020). Before the outbreak of the corona virus towards the end of 2019 , there was a prolonged civil unrest featuring a series of intense political protests, occupy movement and confrontation with armed forces. As part of the results, classes were suspended, offices were closed, shopping malls were vandalized and local universities were occupied and heavily damaged. The District Council election in November was regarded by the pan-democratic wing as their biggest landslide victory in Hong Kong's history against its proconstitution counterpart. The territory, however, does not resume normalcy. The economy of the city has thus been reeling under the effects of the civil unrest, deterioration of business confidence and 
the continuing confrontation of the competing political bodies. The protests are currently halted due to the corona virus pandemic but the "peace" is fragile and could be very short-lived.

This is also important to note that Hong Kong has critical experiences in outbreak of fatal diseases, which included SARS in 2003 and MERS in 2012. For the SARS epidemic, there were over 1,700 confirmed cases and almost 300 death reported.

\section{Methods}

In order to provide a relatively objective and holistic picture about the development of the COVID-19 pandemic incident in Hong Kong, the research adopted a multiple method approach to triangulate the evidence before inducing any insights. The three fundamental methods include an archival analysis of news, administrative papers and secondary data; observation with an auto ethnographic approach; qualitative interviews with key informants with the application of Delphi techniques to dive deeper into the discussion topics.

\section{The case of Hong Kong}

- $\quad$ Soon after the outbreak of a then unknown disease in Wuhan, the HKSAR Government has imposed the requirements of disclosure of past visit history to the wet markets in Wuhan. The requirement was subsequently escalated on 3rd January to anyone who had visited Wuhan within 14days should inform the health authorities.

- On 4th January, University of Hong Kong infectious diseases expert Dr Ho Pak-leung suspected such transmission had happened among cases in Wuhan, and urged "the most stringent" precautionary measures Cheung E [5]. However, press reported that border checks at the West Kowloon high-speed rail terminal were lax at that point in time Zhang [6]. The public immediately demand for a closure of border to all mainlanders.

- $\quad$ On 8th January, Hong Kong's Centre for Health Protection (CHP) added "Severe respiratory disease associated with a novel infectious agent" to their list of modifiable diseases and to expand their authority on quarantine Siu [7]. The Hong Kong government announced the requirement for visitors to wear face masks. Screenings for potential cases were tightened at entry points including airports and train stations with connections to Wuhan Leung [8]. For the first week of 2020, 30 unwell travelers from Wuhan were tested.

- $\quad$ On 20th January, the Centre for Health Protection launched additional precautionary measures to enhance surveillance of suspected cases of novel corona virus infection in view of the latest situation and risk assessment. Medical practitioners are requested to make a report to the centre if they encounter any individual with fever and acute respiratory illness or pneumonia; introducing a health declaration form and new reporting criteria. The public, however, questioned the effectiveness and trustworthiness of these measures.

- $\quad$ On 22ndJanuary, an arrival from Wuhan via Shenzhen by high-speed rail developed symptoms of pneumonia. Another case of a local resident with prior visit to Wuhan also confirmed positive in preliminary screening. The first confirmed case of corona virus disease 2019 in Hong Kong was announced on 23rdJanuary 2020. On the same day, the Lady Mac Lehose Holiday Village was designated as a quarantine centre. The HK Tourism Board cancelled the Lunar New Year Cup and a four-day Lunar New Year Carnival for precaution. Many of the local people has negative sentiments over the cancellations and argued that they are not necessary.

- $\quad$ On 23rd January, the Government extended the health declaration form system to cover all inbound travelers using the high speed rail. Citizens were also urged to avoid visiting Wuhan.

- $\quad$ On 25 January, the Hong Kong government declared the viral outbreak as an "emergency", the highest warning tier. The city's largest amusement parks, Hong Kong Disneyland Resort, Ocean Park Hong Kong, and Madame Tussauds Hong Kong closed from 26 January, until further notice Chan [9].

- A newly built housing block in Fanling was planned to be used as a quarantine facility for people who may have been exposed to Wuhan corona virus. It was, however, fire-bombed as part of the protests against the establishment of the facility in the neighborhood.

- Schools were ordered to extend their Lunar New Year holidays till 17th February so as to safeguard students' health. The measure was subsequently extended to May 7 as of the submission of this paper in late April. Many parents have strong reservations on the decision.

- $\quad$ On 28 January, Chief Executive of Hong Kong Carrie Lam suspended the high-speed rail service and all cross-border ferry services between Hong Kong and mainland China starting from 30 January Gayle [10]. Number of flights from mainland China would be cut in half, cross-border bus services reduced, and the Hong Kong government was asking all its employees (except those providing essential/emergency services) to work from home. The Man Kam To and Sha Tau Kok border checkpoints were also closed Cheung $[11,12]$. There were arguments from the public that it is too late and too conservative.

- $\quad$ On 29th January, The Leisure and Cultural Services Department (LCSD) announced that all their facilities including museums, libraries and sports centers and venues would be closed until further notice LCSD [13], the order was extended on 14 February and 27th March LCSD [14]. On the same day, there were 
rumor saying that the SAR Government has agreed to use Hong Kong's medical system to help the Mainland in tackling the disease. Of which, the Chief Executive has declined.

- The first case of death was reported on 4th February and the number of confirmed cases reached 100 on 2nd March. The Anti-epidemic Fund Committee first met on 26th February to discuss about the relief and support measures.

- $\quad$ On 24th February, red travel alert was issued for Korea. DSE Examination, which is the open examination for universities admissions, was deferred on the next day.

- $\quad$ On 28th February, the Department of Health strengthens health quarantine arrangements on inbound travelers from three regions in Italy after the Government issued the Red Outbound Travel Alert.

- $\quad$ Starting from midnight on 1st March, quarantine orders were issued under the Prevention \& Control of Disease Regulation to people who have been to the three Italian regions or Iran in the past 14 days regardless of whether they are Hong Kong residents. The measure was to cut the possible link of infections but many people questioned its effectiveness.

- $\quad$ On 25 March, Hong Kong closed its border to all incoming nonresidents arriving from overseas and transits was also prohibited. All returning residents, regardless of point of departure, are subject to the Compulsory Quarantine Order, which requires staying at a reported quarantine premise (either home or hotel) for 14 days. Tracking devices were used to enforce the order. All returning residents from the United States, the UK, and continental Europe are required to go through enhanced screening and submit saliva sample for COVID-19 testing (HKSAR Government, 2020).

- On 27th March, The Government announces new regulations to combat the spread of COVID-19, including a ban on gatherings of more than four people in public places. Restaurants are ordered to serve only half of their capacity of customers. Each table needs to be separated by at least $1.5 \mathrm{~m}$ and only four people can be seated at a table. Venues such as cinemas, fitness centres and amusement game centres were ordered to close.

- $\quad$ On 28thMarch, The Agriculture, Fisheries \& Conservation Department (AFCD) today announced that its barbecue sites and campsites in country parks will be closed until May 7. On 21st April, the closure was elongated to 7th May. Many of the local people thought it is not necessary.

- $\quad$ On 30th March, isolation bed criteria were discussed so as to free up more ward for confirmed cases. On the same day, three men are sentenced to jail for violating the Compulsory Quarantine of Certain Persons Arriving at Hong Kong Regulation.

- $\quad$ On 1 April, the Hong Kong government announced the temporary closure of karaoke lounges, nightclubs and mahjong premises. Confusion over the government's listing of venues to be temporarily closed led the public to believe that other venues such as beauty parlors, massage parlors and clubhouses would have to be closed as well. However the government clarified that such establishments would be allowed to remain open subject to businesses providing hand sanitizer to customers, as well as requiring customers to wear a mask and have their temperature taken while inside the business venue.

- $\quad$ On Friday 3 April at 1800 hrs, all pubs and bars across the territory were ordered to close for 14 days (HKSAR Government, 2020).

- $\quad$ As of 23 April, Hong Kong registered 1,034 confirmed cases with 678 recovered and 4 deaths. Singapore, as its common comparative reference, has 10,141 confirmed cases and 12 deaths. The statistics seems to indicate that Hong Kong has been doing well in control the development of the disease. The tactical measures imposed by the HKSAR Government should be contributing to the results. Yet, the general public seems to have different points of view.

The local English newspaper, South China Morning Post, commissioned a poll of about 850 local people. Seven in ten contended that they should take the full credit for winning the battle against COVID-19 Cheung [11]. (Table 1) as cited below highlighted the findings of the poll. Results clearly indicated that the general perceptions in related to the SAR Government's measures were negative. Respondents credited their own efforts in combating the corona virus and expressed their disapproval against the government. The impression of COVID-19 as a critical public health crisis escalated in within a very short period of time. Citizens rushed to panic purchase surgical masks, sanitizers and staples including rice, toilet paper and dried goods. The reactive measures by the HKSAR Government were being accursed for their inefficiency and ineffectiveness despite the fact that Hong Kong seems to have performed much better than nearby countries such as Singapore and Japan. The fear of the people seems not being triggered merely by the sparkled incidents and the escalating number of confirmed cases. There must be some other attributes that induced the sentiments and actions. 
Table 1.

\begin{tabular}{|c|c|c|c|c|c|c|}
\hline$\%$ & Strongly agree & Agree & Neutral & Disagree & Strongly Disagree & No comment \\
\hline $\begin{array}{l}\text { If HK avoids } \\
\text { a large-scale } \\
\text { epidemic, it } \\
\text { will be due to } \\
\text { the community } \\
\text { response. }\end{array}$ & 48.1 & 23.8 & 16.5 & 5.2 & 4.8 & 1.6 \\
\hline $\begin{array}{l}\text { If HK avoids } \\
\text { a large-scale } \\
\text { epidemic, it will } \\
\text { be due to the } \\
\text { government's } \\
\text { handling of the } \\
\text { crisis. }\end{array}$ & 8.1 & 15.9 & 18.3 & 14.7 & 41 & 2.1 \\
\hline $\begin{array}{l}\text { Satisfaction with } \\
\text { government's } \\
\text { measures }\end{array}$ & Very satisfied & Satisfied & Neutral & Dissatisfied & Very dissatisfied & No comment \\
\hline $\begin{array}{l}\text { Immigration } \\
\text { Measures }\end{array}$ & 6.6 & 14.6 & 18.7 & 17.7 & 40.7 & 1.7 \\
\hline $\begin{array}{l}\text { Education } \\
\text { Measures }\end{array}$ & 12.3 & 25.6 & 35.3 & 12.6 & 12.4 & 1.7 \\
\hline $\begin{array}{l}\text { Protective } \\
\text { equipment } \\
\text { procurement }\end{array}$ & 0.3 & 9.6 & 17.5 & 14.8 & 53.2 & 0.6 \\
\hline $\begin{array}{l}\text { Epidemic control } \\
\text { and isolation } \\
\text { measures }\end{array}$ & 8.3 & 16.1 & 25.6 & 20.4 & 28.8 & 1 \\
\hline $\begin{array}{c}\text { Public } \\
\text { consultation work }\end{array}$ & 9 & 16.5 & 28.6 & 14 & 29.1 & 2.8 \\
\hline $\begin{array}{c}\text { Personal negative } \\
\text { impact }\end{array}$ & & Very big & Big & Slightly & No & No comment \\
\hline Finances & & 12.3 & 21.5 & 47.3 & 18.2 & 0.7 \\
\hline Emotions & & 10.1 & 21.9 & 52.8 & 14.9 & 0.2 \\
\hline Social life & & 20.4 & 33.3 & 36.4 & 9.9 & - \\
\hline Daily life & & 21.9 & 29.6 & 36.8 & 11.5 & 0.3 \\
\hline
\end{tabular}

Starting from early February, the researcher has engaged in observations and conversation with local Hong Kong citizen over the issue of COVID-19, their feelings about the situation, their opinions on the Government's measures and their sources of reference. From 3rd February till 3rd April, the researcher conducted visits to local areas on a daily basis and engaged in more than 300 dialogues with local people. Six key informants were selected for in-depth interviews in order to solicit critical inputs. They included a medical doctor, a senior executive of a multi-nation corporation, a housewife, a secondary school teacher, a university student and social worker. Although their background and the limited size of the group make it impossible to generalize knowledge about the population, it served the purpose of solicit opinions and views in related to the phenomenon of concern. Their responses were summarized and presented to other key informant for comments and further inputs. While there is no pre-stated scope for the discussions, the major focus was on the formation of fear and sentiments of the people.

\section{Findings and Discussions}

- $\quad$ There is genuine fear during the outbreak of the COVID-19. The major reasons for the fear can be summarized into three major groups.

- First, the pandemic seems to be severe both in terms of its spreading magnitude and the impacts on health. The prior experience that Hong Kong people have in the cases of SARS and MERS seem to leave them with the post-traumatic stress and anxiety over transmittable diseases. Some have expressed that the experience learnt through SARS and MERS provide critical inputs for combating the novel COVID-19. This, however, seems to be shared only among a small minority.

- $\quad$ Second, the incapability of Government and its health related departments in providing effective measures. Some respondents criticized the Government's gradual approach to locking down the territory was one of the major causes for the pandemic and government should bear the blame for not protecting 
the public's health. For example, they demand the Government to close the borders with the mainland but Government has failed to answer the request. Some others complained that many of the government's measures were too drastic and imposed heavy damages to the people. Of which, the government should be ashamed of its inconsiderate. While there arguments seem to be contradicting, some respondents concerted both.

- Third, the lack of reliable sources of supplies and medical services. The supplies of protective gears were limited especially during the early phases of the outbreak. Although the government has proactively sourcing for supplies, their effects seem to be in vain. It is then followed by the protest and strike of the medical workers. Many of the respondents lost their confidence that they will receive ample and good quality medical services.

- The fear escalated when there were rumors that rice, toilet paper and other staples will be in shortage. While the SAR Government has made several announcements regarding there are stable supplies and abundant inventory of these commodities with the testimonials from trade parties, it failed in preventing citizens to panic purchases of goods.

- The researcher has the perception that the feelings and opinions of the respondents were not grounded with factual knowledge but derived from emotions and unconfirmed information. The research, therefore, attempts to unveil the influences that the respondents have received and their mechanism in assessing and accepting information. Results revealed that many of the respondents were sensitive to the related information but not particularly keen on scrutinizing the credibility of those sources. They tends to be more exceptive to negative information than their positive counterpart. In other words, a message saying that the pandemic is worsening is easier to believe that the message that the situation has been improving. This could be explaining partially by the negativity bias among subject.

- In order to understand better to what extend general public are keep abreast of the development of outbreak, the researcher inquire about respondents' information sources, their comprehension and retention of knowledge. While many respondents claimed that they were aware of the most updated situation, their position can be challenged. The researcher presented some of the announcement by the Government on their daily press conference to the respondents but their knowledge ranged from not aware to partially known. They tend to listen to news reports or read related postings as their main sources of information. Only a very limited portion of the respondents would do a fact check. Many of them have the tendency to focus on certain aspects of the messages or the commentaries as their sources of information. They also tend to use selected sources that concur with their values or believes and discredit those holding a different opinion. The issue of selective exposure seems to be a critical issue that the authority has to overcome before effective communication can be in place. The researcher also attempt to ask respondents on the daily number of confirmed cases at around 8pm on selected weekdays, which is 4 hours after the daily press conference by the Government and one hour after the evening news on local TV channel. Only a small portion of the respondents can produce the correct answer.

- $\quad$ The respondents also demonstrated selective distortion on messages and information. They tends to have their own interpretations on the message that they get. For example, when the Government refuse to totally close the border, it was interpreted as a political decision. When the Government said that Hong Kong still have spare capacity in handling COVID-19 cases, they interpret that it is Government's intention to use Hong Kong's resources to help treating cases from the Mainland. Another example is that many people queried the trustworthiness of the Government and the trade union when they claimed that there are sufficient supplies and stock of rice in Hong Kong.

- $\quad$ The last but not the least, there are many questionable messages, comments and claims avail in the community. These sources include but not limited to politicians, ex-government officials, academia, press and more importantly social media and peer influences. The HKSAR Government has launched a series of advertisements urging people to fact check before believing in information and messages. Hearsay has its issue of reliability and might have far-reaching consequences. These warming's, however, do not seem to have much effectiveness. It is also worthy to note that some newspapers and/or broadcasting stations admitted that their reports were sometimes based on hearsay. $b$ Their news stories, therefore, can be constructed in a misleading way.

\section{Conclusion}

As a conclusion, it is obvious that there are critical gaps in communication which lead to the conflicts and confrontation between the Government and some of the local people. This has critically affected the effectives of some measure on the mitigating measures. It also jeopardized the harmony amongst local communities. The local influencers in particularly the press, politicians and opinion leaders would have a critical part to play. Their influences are sometime even more critical than those coming from authoritative medical experts.

In order to rectify the situation and to improve the governance effectiveness, better communication is essential in minimizing undesirable selective exposure, selective distortion and selective retention of information. This can only be achieved through critical improvement in the construction of messages, soliciting of testimonials, lobbying of various competing interest, effective 
dissemination mechanism and creative uses of new media. With the backdrop of a fast evolving context both in terms of technology and social fabrication, a new systematic approach to public communication and relationship would be essential. Such a scheme would not only improve the governance efficiency but also the effectiveness of the anti-pandemic measures. This study is subject to a list of limitations. Owing to the selected method and the scale of sampling, findings cannot be generalized as the characteristics of the Hong Kong. They, however, revealed some of the important aspects in related to the subject issue and can serve as a swinging board to a large scale research project.

\section{References}

1. World meters (2020) COVID-19 Coronavirus Pandemic. Retrieved from world meter.

2. WHO (2020) Coronavirus Disease (COVID-19) Pandemic. Retrieved from World Health Organization 4-23.

3. WHO (2003) Update 49-SARS case fatality ratio, incubation period. Retrieved from WHO

4. WHO (2019) Middle East respiratory syndrome corona virus (MERSCoV): key facts. Retrieved from WHO.

5. Cheung E (2020) Hong Kong activates 'serious response level' for infectious diseases as Wuhan pneumonia outbreak escalates. SCMP.

ISSN: $2574-1241$

DOI: 10.26717/BJSTR.2020.27.004517

Leung Kin Hang Paul. Biomed J Sci \& Tech Res

(C) This work is licensed under Creative

Submission Link: https://biomedres.us/submit-manuscript.php
6. Zhang K (2020) China pneumonia: Hong Kong authorities take low-key approach to passengers arriving in Hong Kong on Wuhan trains. SCMP.

7. Siu P (2020) Hong Kong to add mystery Wuhan pneumonia to list of notifiable infectious diseases, giving authorities power to quarantine patients. SCMP.

8. Leung H (2020) What to Know About the Wuhan Pneumonia Outbreak. Time.

9. Chan Hh (2020) China corona virus forces Andy Lau to call off Hong Kong concerts, following closures of Disneyland, Ocean Park until further notice. SCMP.

10. Gayle D, Rourke A (2020) Coronavirus Live. Retrieved from The Guardian.

11. Cheung T, Wong N (2020) Coronavirus: Hong Kong residents unhappy with Covid-19 response-and surgical mask one big reason why, Post survey shows. SCMP.

12. Cheung T, Lum A, Cheung E, Sum Lk (2020) China corona virus: Hong Kong scrambles to roll out containment plan stopping short of total closure, with cuts on cross-border travel and reduced transport services with mainland. SCMP.

13. LCSD (2020) Press Releases. Retrieved from Leisure and Cultural Services Department.

14. LCSD (2020) Press Releases. Retrieved from Leisure and Cultural Services Department.

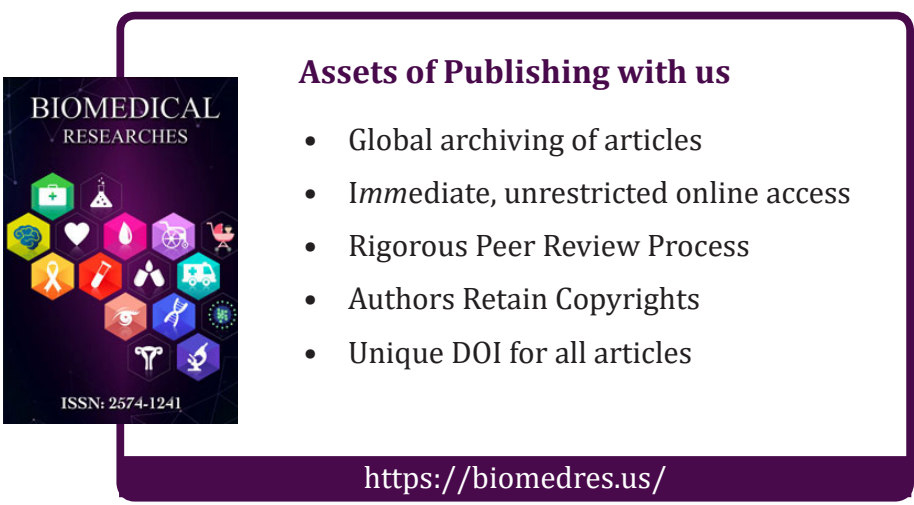

